\title{
HUBUNGAN MEDIA INFORMASI TERHADAP PENGETAHUAN, SIKAP DAN TINDAKAN PENCEGAHAN PENULARAN COVID-19 PADA MASYARAKAT
}

\author{
Edriyani Yonlafado Simanjuntak ${ }^{1 *}$, Marlina $^{2}$, \\ Program Studi Keperawatan, Fakultas Farmasi dan Ilmu Kesehatan \\ Univerisitas Sari Mutiara Indonesia ${ }^{1}$ \\ Mahasiswa Program Studi Keperawatan, Fakultas Farmasi dan Ilmu Kesehatan \\ Univerisitas Sari Mutiara Indonesia ${ }^{2}$ \\ *Email: edriyani260481@gmail.com, sinagamarlina29@gmail.com
}

\begin{abstract}
Abstrak
Coronavirus (CoV) merupakan keluarga besar virus yang dapat menyebabkan penyakit mulai dari gejala ringan sampai berat. Saat ini dunia mengalami pandemi akibat Novel Coronavirus (NCoV) yang dikenal dengan Covid-19. Dalam mengantisipasi penularan dan memperlambat penyebaran virus corona, salah tindakan dilakukan dengan sosialisasi atau memberikan informasi tentang pencegahan penularan Covid-19 melalui media informasi. Media informasi sangat berperan penting dalam menyebarkan informasi terkait pencegahan penularan Covid-19. Tujuan dari penelitian ini adalah untuk mengetahui hubungan media informasi dengan pengetahuan, sikap dan tindakan pencegahan penularan Covid-19 pada masyarakat Desain penelitian ini merupakan penelitian kuantitatif dengan deskritif korelasi dan rancangan cross sectional. Populasinya adalah masyarakat di kelurahan Pelangai Gadang Kec. Ranah Pesisir Kab.Pesisir Selatan sebanyak 124 kepala keluarga berjumlah 496 orang. Sampel penelitian ini berjumlah 83 orang dengan menggunakan tehnik purposive sampling dan data dianalisis menggunakan uji spearman rank. Hasil penelitian menunjukkan mayoritas penggunaan 5 media informasi kategori baik $(30,1 \%)$, pengetahuan kategori baik (86,7\%), sikap kategori baik $(72,3 \%)$, dan tindakan pencegahan penularan Covid-19 kategori baik (96,4\%). Hasil uji statistik menunjukkan hubungan media informasi dengan pengetahuan dengan nilai $\mathrm{p}=0,006 ; \mathrm{r}=0,308$, media informasi dengan sikap dengan nilai $\mathrm{p}=0,003 ; \mathrm{r}=0,320$ dan media informasi dengan tindakan nilai $\mathrm{p}=0,028 ; \mathrm{r}=0,241$ Kesimpulan penelitian ini adalah ada hubungan media informasi dengan pengetahuan, sikap dan tindakan pencegahan penularan Covid-19 dengan keeratan hubungan cukup.
\end{abstract}

Kata Kunci : Covid-19, Media Informasi, Pengetahuan, Sikap, Tindakan.

\begin{abstract}
Coronaviruses (CoV) are a large family of viruses that can cause illness ranging from mild to severe symptoms. The world is currently experiencing a pandemic due to the Novel Coronavirus (NCoV), known as Covid-19. In anticipating transmission and slowing the spread of the corona virus, one of the actions that can be taken is to disseminate or provide information about preventing the transmission of Covid-19 through information media. Information media plays an important role in disseminating information related to preventing the transmission of Covid-19. The purpose of this study was to determine the relationship of information media to knowledge, attitudes and prevention of Covid-19 transmission in the community. The design of this research is quantitative research with correlational and cross sectional descriptive design. The population is the community in Pelangai Gadang Village, Kec. Pesisir Selatan Regency has 124 families with a total of 496 people. The sample of this study was 83 people using purposive sampling technique and the data were analyzed using the Spearman rank test. The results showed that most of the use of 5 information media in the good category (30.1\%), knowledge in the good category (86.7\%), attitudes in the good category (72.3\%), and the prevention of Covid-19 transmission were in the good category. in the good category. in the good category (96.4). \%). Statistical test results show the relationship between information media and knowledge with $p$ value $=0.006 ; r=0.308$, information media with attitude with $p$ value $=0.003 ; r=0.320$ and media information with $a$
\end{abstract}


value of $p=0.028 ; r=0.241$ The conclusion of this study is that there is a relationship between information media and knowledge, attitudes and preventive measures for Covid-19 transmission with sufficient closeness.

Keywords: Covid-19, Information Media, Knowledge, Attitude, Action.

\section{Pendahuluan}

Pada awal tahun 2020 Covid-19 kita ketahui menjadi masalah kesehatan dunia. Dalam waktu tiga bulan, virus telah menyebar lebih dari 118.000 kasus dan menyebabkan 4.291 kematian di 114 negara, yang menyebabkan Organisasi Kesehatan Dunia mendeklarasikan pandemi global. Kasus ini diawali dengan informasi dari Badan Kesehatan Dunia atau World Health Organization (WHO) pada tanggal 31 Desember 2019 yang menyebutkan adanya kasus pneumonia dengan etiologi yang tidak jelas di Kota Wuhan, Provinsi Hubei, China (WHO, 2020).

Pada tanggal 7 Januari 2020, Cina mengidentifikasi pneumonia yang tidak diketahui etiologinya tersebut sebagai jenis baru coronavirus (coronavirus disease, Covid-19). Penambahan jumlah kasus berlangsung cukup cepat dan menyebar ke luar wilayah Wuhan dan negara lain (Kemenkes, 2020). WHO juga menyatakan hingga sampai saat ini kasus corona tersebar di 213 negara dan bertambah menjadi 2.498.999, 171.334 kematian dan 657.895 pasien sembuh di seluruh dunia hingga pada tanggal 21 April 2020 (Kemenkes RI, 2020).

Di Indonesia Pemerintah telah mengeluarkan status darurat bencana terhitung tanggal 29 Februari 2020. Tanggal 02 Juni 2020 jumlah kasus positif Covid-19 adalah 27.549 kasus, pasien sembuh 7.935 orang dan pasien meninggal 1.663 orang. Di Sumatera Barat tanggal 02 Juni 2020 Orang Dalam Pemantauan (ODP) adalah 9.199 orang, Pasien Dalam Pengawasan (PDP) adalah 1.039 orang, dan kasus terkonfirmasi COVID-19 adalah 574 kasus positif. Jumlah kasus penyebaran COVID-19 di Kabupaten Pesisir Selatan, Sumatera Barat meningkat dari jumlah sebelumnya. Jumlah pasien Dalam Pengawasan (PDP) sebelumnya 1 orang kini bertambah menjadi 3 orang. Begitu juga dengan Orang Dalam Pemantauan (ODP) sebelumnya 6 orang kini bertambah menjadi 11 orang. Serta orang dengan status notifikasi sebelumnya 130 orang kini bertambah menjadi 147 orang akibat penyebaran virus corona (COVID-19) yang terus merebak saat ini.(Diskominfo Provinsi Sumbar, 2020).

WHO melaporkan bahwa penularan dari manusia ke manusia terbatas (pada kontak erat dan petugas kesehatan) telah dikonfirmasi di China maupun negara lain. Rekomendasi standar untuk mencegah penyebaran infeksi adalah melalui cuci tangan secara teratur, menerapkan etika batuk dan bersin, menghindari kontak secara langsung dengan ternak dan hewan liar serta menghindari kontak dekat dengan siapa pun yang menunjukkan gejala penyakit pernapasan seperti batuk dan bersin. Manifestasi klinis yang muncul pada virus corona terjadi dalam 2 hari hingga 14 hari setelah paparan. Gejala yang muncul berupa demam, batuk dan sesak napas. Pada kasus-kasus yang lebih parah, menyebabkan radang paru-paru atau kesulitan bernapas (WHO, 2020).

Langkah-langkah yang telah dilakukan oleh pemerintah salah satunya adalah mensosialisasikan atau memberikan informasi melalui media elektronik maupun media cetak terkait gerakan social distancing, penggunaan masker, mencuci tangan, bekerja, belajar dan ibadah dirumah. Media sangat berperan penting dalam menyebarkan informasi terkait pencegahan Covid-19. Informasi yang diperoleh masyarakat lebih banyak didapat melalui media informasi seperti TV dan koran dimana jaman sekarang teknologi telah berkembang sangat pesat. Selain itu, media yang memberikan informasi tentang Covid-19 ini adalah media elektronik seperti smartphone, komputer, radio, televisi, internet) dan media cetak seperti koran, majalah, brosur, spanduk, pamphlet, 
buku dan lain sebagainya. Pemberian informasi melalui media elektronik dan cetak dapat membantu mengurangi bahkan memutus mata rantai infeksi Covid-19 (BNPB, 2020).

Selain itu, upaya mengubah perilaku masyarakat untuk peningkatan derajat kesehatan melalui program Pembinaan Perilaku Hidup Bersih dan Sehat (PHBS). Salah satu evaluasi keberhasilan pembinaan PHBS dilakukan dengan melihat indikator PHBS di tatanan rumah tangga (Kemenkes, 2011). PHBS pada dasarnya sebuah upaya untuk menularkan pengalaman mengenai pola hidup sehat melalui individu, kelompok ataupun masyarakat luas dengan jalur-jalur komunikasi sebagai media berbagi informasi (Kemenkes, 2016).

Berdasarkan survey pendahuluan yang dilakukan di Kel. Pelangai Gadang Kec. Ranah Pesisir Kab. Pesisir Selatan, masyarakat yang belum menjalankan anjuran pemerintah untuk menekan penyebaran Covid-19 seperti tidak memakai masker bila keluar rumah, berkerumun ditempat ramai, dan tidak menjaga jarak. Dilakukan wawancara pada beberapa masyarakat mengatakan mereka keluar rumah untuk memenuhi kebutuhan sehari-hari dan kurang tidak paham akan risiko terpapar COVID19. Mereka juga mengatakan jarang mencuci tangan saat selesai beraktivitas dari luar. Penting membangun kesadaran dan perilaku masyarakat akan bahaya virus corona. Tujuan penelitian ini adalah untuk mengetahui hubungan media informasi terhadap pengetahuan, sikap dan tindakan pencegahan penularan Covid-19 pada masyarakat.

\section{Metode Penelitian}

Penelitian ini adalah penelitian kuantitatif dengan jenis penelitian deskritif korelasi dan rancangan cross sectional. Populasinya adalah seluruh masyarakat di Kelurahan Pelangai Gadang Kec.Ranah Pesisir Kab.Pesisir Selatan sebanyak 124 KK yang berjumlah 496 orang. Pengambilan sampel menggunakan teknik purposive sampling dan diperoleh dengan 83 orang dengan kriteria inklusi yaitu masyarakat bersedia menjadi sampel penelitian, mendapatkan penjelasan penelitian, dan menandatangani informed consent, usia minimal 17 tahun, memiliki smartphone dan aplikasi Whatsapp dan bisa membaca, sedangkan kriteria eksklusi adalah masyarakat gangguan penglihatan.

Instrumen penelitian menggunakan kuesioner yang telah diuji validitasnya oleh expert dan reliabilitas yaitu pengetahuan dengan Cronbach's Alpha 0.854, Sikap Cronbach's Alpha 0,912 dan tindakan pencegahan Cronbach's Alpha 0,856. Penelitian ini juga telah lolos uji etik oleh Komite Etik Penelitian USM-Indonesia dengan Nomor 477/F/KEP/USM/X/2020.

\section{Hasil dan Pembahasan Hasil}

Tabel 1.

Distribusi Frekuensi Karakteristik Responden (n=83)

\begin{tabular}{lcc}
\hline Karakteristik & $\begin{array}{c}\text { Frekuensi } \\
\text { (f) }\end{array}$ & $\begin{array}{c}\text { Persentase } \\
(\mathbf{\%})\end{array}$ \\
\hline Umur & 31 & \\
17-25 tahun & 31 & 37,3 \\
26-35 tahun & 52 & 62,7 \\
\hline Jenis Kelamin & & \\
Laki-laki & 65 & 78,3 \\
Perempuan & 18 & 21,7 \\
\hline Pendidikan & & \\
SMA & 17 & 20,5 \\
PT & 66 & 79,5 \\
\hline
\end{tabular}




\begin{tabular}{lcc}
\hline Pekerjaan & & \\
Tidak bekerja & 18 & 21,7 \\
Wiraswasta & 18 & 21,7 \\
PNS & 3 & 3,6 \\
Siswa/mahasiswa & 44 & 53,0 \\
\hline
\end{tabular}

Tabel 2.

Distribusi Frekuensi Penggunaan Media Informasi Terkait Covid-19 Pada Masyarakat $(\mathbf{n}=83)$

\begin{tabular}{ccc}
\hline $\begin{array}{c}\text { Media Informasi } \\
\text { Covid-19 }\end{array}$ & $\begin{array}{c}\text { Frekuensi } \\
(\mathbf{f})\end{array}$ & $\begin{array}{c}\text { Persentase } \\
(\boldsymbol{\%})\end{array}$ \\
\hline 1 media & 11 & 13,3 \\
2 media & 10 & 12,0 \\
3 media & 22 & 26,5 \\
4 media & 15 & 18,1 \\
5 media & 25 & 30,1 \\
\hline
\end{tabular}

Tabel 3.

Distribusi Frekuensi berdasarkan Pengetahuan, Sikap dan Tindakan Pencegahan Penularan Covid-19 Pada Masyarakat (n=83)

\begin{tabular}{lccc}
\hline \multicolumn{2}{c}{ Pencegahan Covid-19 } & $\begin{array}{c}\text { Frekuensi } \\
\text { (f) }\end{array}$ & $\begin{array}{c}\text { Persentase } \\
(\boldsymbol{\%})\end{array}$ \\
\hline \multicolumn{2}{c}{ Pengetahuan: } & 72 & 86,7 \\
& Baik & 11 & 13,3 \\
\hline Sikap: & Cukup & & \\
& Baik & 60 & 72,3 \\
& Cukup & 23 & 27,7 \\
\hline Tindakan: & & & \\
& Baik & 80 & 96,4 \\
& Cukup & 3 & 3,6 \\
\hline
\end{tabular}

Tabel 4.

Tabulasi Silang Hubungan Media Informasi Dengan Pengetahuan Pencegahan Penularan Covid-19 pada Masyarakat

\begin{tabular}{|c|c|c|c|c|c|c|c|c|}
\hline \multirow{3}{*}{$\begin{array}{c}\text { Media } \\
\text { Informasi }\end{array}$} & \multicolumn{6}{|c|}{ Pengetahuan Pencegahan COVID-19 } & \multirow{3}{*}{$p$ value } & \multirow{3}{*}{$r$} \\
\hline & \multicolumn{2}{|c|}{ Baik } & \multicolumn{2}{|c|}{ Cukup } & \multicolumn{2}{|c|}{ Total } & & \\
\hline & $\mathrm{n}$ & $\%$ & $\mathrm{~N}$ & $\%$ & $\mathrm{n}$ & $\%$ & & \\
\hline 1 media & 11 & 13.2 & 0 & 0 & 11 & 13.2 & \multirow{6}{*}{0,006} & \multirow{6}{*}{0,308} \\
\hline 2 media & 10 & 12,1 & 0 & 0 & 10 & 12.1 & & \\
\hline 3 media & 20 & 24.1 & 2 & 2.4 & 22 & 26.5 & & \\
\hline 4 media & 13 & 15.7 & 2 & 2.4 & 15 & 18.1 & & \\
\hline 5 media & 18 & 21.7 & 7 & 8.4 & 25 & 30.1 & & \\
\hline Total & 72 & 86,8 & 11 & 13,2 & 83 & 100 & & \\
\hline
\end{tabular}

Tabel 5.

Tabulasi Silang Hubungan Media Informasi Dengan Sikap Pencegahan Penularan Covid-19 Pada Masyarakat

\begin{tabular}{|c|c|c|c|c|c|c|c|c|}
\hline \multirow{3}{*}{$\begin{array}{c}\text { Media } \\
\text { Informasi }\end{array}$} & \multicolumn{6}{|c|}{ Sikap Pencegahan COVID-19 } & \multirow{3}{*}{ p value } & \multirow{3}{*}{$\boldsymbol{R}$} \\
\hline & \multirow{2}{*}{$\begin{array}{c}\text { Baik } \\
\text { n }\end{array}$} & \multicolumn{2}{|r|}{ Cukup } & \multicolumn{3}{|c|}{ Total } & & \\
\hline & & $\%$ & $\mathbf{N}$ & $\%$ & $\mathbf{n}$ & $\%$ & & \\
\hline 1 media & 8 & 9.6 & 3 & 3.6 & 11 & 13.2 & & \\
\hline 2 media & 10 & 12.1 & 0 & 0 & 10 & 12.1 & 0,003 & 0,320 \\
\hline 3 media & 19 & 22.9 & 3 & 3.6 & 22 & 26.5 & & \\
\hline
\end{tabular}




\begin{tabular}{ccccccc}
4 media & 11 & 13.2 & 4 & 4.8 & 15 & 18.1 \\
5 media & 12 & 14.5 & 13 & 15.7 & 25 & 30.1 \\
\hline Total & 60 & 72.3 & 23 & 27,7 & 83 & 100 \\
\hline
\end{tabular}

Tabel 6.

Tabulasi Silang Hubungan Media Informasi Dengan Tindakan Pencegahan

Penularan Covid-19 Pada Masyarakat

\begin{tabular}{|c|c|c|c|c|c|c|c|c|}
\hline \multirow{3}{*}{$\begin{array}{c}\text { Media } \\
\text { Informasi }\end{array}$} & \multicolumn{6}{|c|}{ Tindakan Pencegahan COVID-19 } & \multirow{3}{*}{ p value } & \multirow{3}{*}{$\boldsymbol{R}$} \\
\hline & \multirow{2}{*}{$\begin{array}{c}\text { Baik } \\
\mathbf{n}\end{array}$} & & \multicolumn{2}{|l|}{ Cukup } & \multicolumn{2}{|c|}{ Total } & & \\
\hline & & $\%$ & $\mathbf{N}$ & $\%$ & $\mathbf{N}$ & $\%$ & & \\
\hline 1 media & 11 & 13.2 & 0 & 0 & 11 & 13.2 & \multirow{6}{*}{0,028} & \multirow{6}{*}{0,241} \\
\hline 2 media & 10 & 12.1 & 0 & 0 & 10 & 12.1 & & \\
\hline 3 media & 22 & 26.5 & 0 & 0 & 22 & 26.5 & & \\
\hline 4 media & 15 & 18.1 & 0 & 0 & 15 & 18.1 & & \\
\hline 5 media & 22 & 26.5 & 3 & 3.6 & 25 & 30.1 & & \\
\hline Total & 80 & 96.4 & 3 & 3,6 & 83 & 100 & & \\
\hline
\end{tabular}

\section{Pembahasan}

Hubungan media informasi dengan pengetahuan pencegahan penularan Covid-19

Berdasarkan hasil uji statistik Spearman Rank diperoleh $p$ value $=0,006(\mathrm{p}<0,05)$ artinya bahwa ada hubungan media informasi dengan pengetahuan pencegahan penularan Covid-19. Dari hasil ini juga terlihat nilai correlation coefficient sebesar 0,308 menunjukkan hubungan media informasi terhadap pengetahuan pencegahan COVID-19 memiliki hubungan yang cukup.

Coronavirus (COVID-19) adalah penyakit menular yang disebabkan oleh coronavirus yang sebagian besar gangguan dialami oleh individu yang terinfeksi virus ini akan mengalami penyakit pernapasan ringan hingga sedang dan sembuh tanpa memerlukan perawatan khusus (Sampurno dkk., 2020). Pada situasi pandemi wabah COVID-19, media informasi menjadi tempat paling dicari masyarakat untuk pengumpulan informasi (Brindhaet al., 2020). Masyarakat memerlukan informasi tentang coronavirus guna meningkatkan perilaku dalam mengantisipasi penyebaran virus ini melalui media informasi (Nurislaminingsih, 2020).

Penelitian ini sejalan dengan Reuben et al (2020) bahwa ada hubungan yang signifikan antara pengetahuan tentang Covid-19 dengan tindakan pencegahan COVID-19 ( $\mathrm{p}=0.004$; $\mathrm{r}=0.177)$.

\section{Hubungan Media Informasi dengan Sikap Pencegahan Penularan Covid-19}

Berdasarkan hasil uji statistik Spearman Rank diperoleh $p$ value $=0,003(\mathrm{p}<0,05)$ artinya bahwa ada hubungan media informasi dengan sikap pencegahan penularan Covid-19. Nilai correlation coefficient adalah 0,320 menunjukkan hubungan media informasi dengan pengetahuan pencegahan penyebaran Covid-19 memiliki hubungan yang cukup.

Pengetahuan yang cukup tentang pencegahan Covid-19, akan menyebabkan seseorang memiliki sikap positif terhadap hal tersebut. Sejalan dengan pendapat yang dikemukakan oleh Notoatmodjo (2014) bahwa sikap merupakan reaksi atau respon yang masih tertutup dari seseorang terhadap suatu objek.Sikap yang positif akan suatu objek akan mempengaruhi seseorang dalam bertindak dan ikut serta dalam suatu tindakan tersebut misalnya pencegahan penularan Covid-19.

Kurangnya pengetahuan yang menyebabkan masyarakat di Indonesia tidak memiliki sikap yang positif akan pencegahan penularan Covid-19. Hal tersebut sejalan dengan hasil penelitian yang dilakukan oleh Reuben et al (2020) yang menyatakan ada hubungan yang signifikan antara sikap dengan tindakan pencegahan COVID-19 $\mathrm{p}=0.001 ; \mathrm{r}=0.137$ ).

Hubungan Media Informasi dengan Tindakan Pencegahan Penularan Covid-19 
Berdasarkan hasil uji statistik Spearman Rank diperoleh $p$ value $=0,028(\mathrm{p}<0,05)$ yang berarti ada hubungan media informasi dengan tindakan pencegahan penularan Covid-19. Nilai correlation coefficient sebesar 0,241 menunjukkan bahwa hubungan media informasi dengan tindakan pencegahan Covid-19 memiliki hubungan yang cukup. Paparan media informasi dapat menjadi salah satu faktor yang dapat memberikan pengaruh terhadap perilaku pencegahan penyebaran Covid-19. Menurut Chaffe yang dikutip dalam penelitian Novasari dkk (2016), media informasi mempunyai efek yang berkaitan dengan perubahan sikap, perasaan, dan perilaku dari komunikasinya. Setiap informasi yang akan disampaikan kepada khalayak luas dengan menggunakan media dalam menyampaikannya.

Kementerian Kesehatan RI telah mengemukakan beberapa tindakan untuk pencegahan infeksi Covid-19 antara lain melakukan kebersihan tangan menggunakan hand sanitizer jika tangan tidak terlihat kotor atau cuci tangan dengan sabun jika terlihat kotor; menghindari menyentuh mata, hidung dan mulut; terapkan batuk atau bersin dengan menutup hidung dan mulut dengan lengan atas bagian dalam atau tisu, lalu buanglah tisu pada tempat sampah; pakailah masker medis jika memiliki gejala masalah pernafasan dan melakukan kebersihan tangan setelah membuang masker; dan menjaga jarak (minimal 1 meter) dari orang yang megalami gejala gangguan pernafasan (Kemenkes RI, 2020).

Namun kenyataannya tidak semua masyarakat mematuhi ketetapan tersebut. Hasil penelitian Triyanto et al (2020) menyatakan bahwa hanya 10\% masyarakat yang memiliki kebiasaan cuci tangan dan memakai masker. Adanya paparan media informasi menyebabkan masyarakat memperoleh informasi yang lebih banyak dibandingkan mereka yang tidak pernah terpapar media informasi tentang pencegahan Covid-19. Individu yang memperoleh informasi dapat menentukan bagaimana bereaksi dan membuat keputusan saat menghadapi masalah (Yanti et al., 2020). Informasi yang didapatkannya akan mempengaruhi masyarakat untuk bertindak atau melakukan perilaku pencegahan penularan Covid-19 (Sidik, 2015).]

Berdasarkan hasil penelitian ini dapat dinyatakan bahwa ada hubungan media informasi terhadap pengetahuan, sikap dan tindakan pencegahan Covid-19. Hasil penelitian ini sejalan dengan penelitian yang dilakukan oleh Liu (2020) yang menyatakan bahwa ada hubungan media digital terhadap perilaku pencegahan covid-19. Studi ini memberikan penjelasan bukti empiris bahwa informasi terkait Covid-19 di berbagai media digital dapat memicu perilaku pencegahan penularan Covid-19 secara langsung maupun tidak langsung.

Hasil penelitian ini juga sesuai dengan penelitian Oh et al (2020) yang menyatakan bahwa penggunaan media sosial secara signifikan dapat meningkatkan perilaku pencegahan wabah penyakit menular. Triyanto dan Kusumawardani (2020) juga menyatakan bahwa media menjadi faktor yang mempengaruhi perilaku pencegahan Covid-19.

Pemanfaatan media dapat memotivasi terjadinya perilaku yang positif dari penggunanya (Sidik, 2015). Sebagaimana yang dikutip oleh Syaipudin (2020) mengatakan bahwa media secara garis besar adalah manusia, materi atau kejadian yang membangun kondisi membuat seseorang mampu memperoleh pengetahuan, keterampilan atau sikap. Sehingga dari penelitian ini terlihat bahwa media informasi berhubungan secara signifikan terhadap pengetahuan, sikap dan tindakan pencegahan Covid-19.

\section{Kesimpulan}

Hasil penelitian dapat disimpulkan berdasarkan analisa univariat bahwa mayoritas penggunaan 5 media informasi kategori baik $(30,1 \%)$, pengetahuan kategori baik $(86,7 \%)$, sikap kategori baik (72,3\%), dan tindakan pencegahan penularan Covid-19 kategori baik (96,4\%). Hasil analisa bivariat menunjukkan hubungan media informasi dengan pengetahuan dengan nilai $\mathrm{p}=$ 0,$006 ; \mathrm{r}=0,308$, media informasi dengan sikap dengan nilai $\mathrm{p}=0,003 ; \mathrm{r}=0,320$ dan media informasi dengan tindakan nilai $\mathrm{p}=0,028 ; \mathrm{r}=0,241$ yang artinya ada hubungan media informasi dengan pengetahuan, sikap dan tindakan pencegahan penularan Covid-19 dengan keeratan hubungan cukup.

\section{Referensi}


Brinda, et al. (2020). Social Media Reigned by Information or Misinformation about COVID-19: A Phenomenological Study. SSRN Electronic Journal, Vol 9, ed (3).

Catrin, dkk. (2020). World Health Organization declares global emergency: A review of the 2019 novel coronavirus (COVID-19). International Journal of Surgery: United Kingdom.

Doni Monardo. (2020). Pedoman penanganan cepat medis dan kesehatan masyarakat COVID-19 di Indonesia. BNBP: Jakarta.

John M Clements. (2020). Knowledge and behaviors toward COVID-19 among U.S. residents during the early days of the pandemic. Doi:https://doi.org/10.1101/2020.03.31.20048967

Keliat, B.A. (2020). Dukungan Kesehatan Jiwa dan Psikososial (Mental Health and Psychosocial Support COVID-19: Keperawatan Jiwa. Ikatan Perawat Kesehatan Jiwa Indonesia (IPKJI): Bogor.

Kemenkes RI. (2020). Jumlah Pasien Corona Sembuh Melebihi Angka Meninggal. Kementerian Kesehatan Republik Indonesia: Jakarta.

Kemenkes RI. (2020). Pedoman Kesiapsiagaan Menghadapi COVID-19. Kementerian Kesehatan Republik Indonesia: Jakarta.

Kemenkes R.I. (2020). Pedoman Pencegahan dan Pengendalian Coronavirus Disease (Covid-19). Jakarta: Direktorat Jenderal Pencegahan dan Pengendalian Penyakit Kementerian Kesehatan Republik Indonesia.

Kemenkes RI. (2016). Prilaku Hidup Bersih dan Sehat. Kementerian Kesehatan Republik Indonesia: Jakarta.

Kemenkes RI. (2011). Perilaku Hidup Bersih dan Sehat. Kementerian Kesehatan Republik Indonesia: Jakarta.

Khayyriyyah Mohd Hanafiah and Chang Da Wan, 2020. Public knowledge, perception and communication behavior surrounding COVID-19 in Malaysia.

Liu PL. (2020). COVID-19 Information Seeking on Digital Media and Preventive Behaviors: The Mediation Role of Worry. Cyberpsychology, behavior, and social networking, Vol 0, ed (0).

Notoatmdjo, S. (2014).Ilmu Perilaku Kesehatan. Jakarta: Rineka Cipta.

Novasari, dkk. (2016). Hubungan pengetahuan, sikap dan paparan media informasi dengan praktik pemeriksaan payudara sendiri (sadari) pada santriwati pondok pesantren al ishlah tembalang semarang tahun 2016. Jurnal Kesehatan Masyarakat, Vol 4, ed (4).

Nurislaminingsih, R. (2020). Layanan Pengetahuan tentang Covid-19 di Lembaga Informasi.Jurnal Ilmu Perpustakaan dan Informasi, Vol 4, ed (1).

Oh, et al. (2020). The Effects of Social Media Use on Preventive Behaviors during Infectious Disease Outbreaks: The Mediating Role of Self-relevant Emotions and Public Risk Perception. Health Communication, Vol 1, ed (10).

Sampurno, dkk. (2020). Budaya Media Sosial, Edukasi, Masyarakat dan Pandemi Covid-19. Jurnal Sosial dan Budaya Syari'I, Vol 7, ed(6).

Sanders, dkk. (2020). Pharmacologic Treatments for Coronavirus Disease 2019 (COVID-19): A Review: JAMA - Journal of the American Medical Association: Dallas.

Setiawan, Kolom Danny. (2020). Apa Yang Harus dilakukan Masyarakat untuk Cegah Penularan Covid-19. Kementerian Kesehatan Republik Indonesia: Jakarta.

Sidik, T.A. (2015). Hubungan media informasi dengan tingkat pengetahuan kesehatan reproduksi pada santri di Pondok Pesantren Darut Taqwa Bulusan Semarang.Jurnal Kesehatan Masyarakat, Vol 3, ed (3).

Sugiyanti, dkk.Beberapa Faktor Yang Berhubungan Dengan Perilaku Pemeriksaan Payudara Sendiri (Sadari) Pada Wanita Di Desa Tambak Agung Kecamatan Kaliori Kabupaten Rembang. 2013

Susilo, dkk.(2020). Coronavirus Disease 2019. Tinjauan Literatur Terkini. Jurnal Penyakit Dalam Indonesia: Jakarta.

Syaipudin, L. (2020). Peran komunikasi massa di tengah pandemi covid-19 (Studi Kasus di Gugus Tugas Percepatan Penanganan Covid-19 Kabupaten Tulungagung). Kalijaga, Vol 2, ed (1). 


\section{JINTAN : Jurnal Ilmu Keperawatan}

ISSN 2774-468X (Media Online)

Vol 1, No 2, Bulan Juli 2021

Hal 68-75

Triyanti, et al. (2020). An Analysis of Pepole's Behavioral Change to Prevent Covid-19 Transmission Based On Integrated Behaviour Model. Jurnal Keperawatan Soedirman, Vol 15, ed (2).

Unhale, dkk. (2020). A Review on Corona Virus (Covid-19) Vol. 6 (109-115). World Journal of Pharmaceutical and Life Sciences: India.

Yanti, et al. (2020).Community knowledge, attitudes, and behavior towards social distancing policy as a means of preventing transmission of covid-19 in Indonesia.Jurnal Administrasi Kesehatan Indonesia, Vol 8, ed (1).

Yuliana.(2020). Corona virus diseases (Covid -19); Sebuah Tinjauan Literature. Wellness and Healthy Magazine: Lampung.

Yurianto, A. (2020). Pasien Positif Covid-19 Capai 10 Ribu. Kementerian Kesehatan Republik Indonesia: Jakarta.

World Health Organization (WHO). (2020). Rational Use of Personal Protective Equipment for Coronavirus Disease 2019 ( COVID-19): WHO: Geneva. 